\title{
Effect of Priming on Yield and Yield Components of Soybean [Glycine max (L.)Merrill] Varieties at Assosa, Western Ethiopia
}

\author{
Meseret Ejeta Dinsssa \\ Department of Seed Science and Technology, Holetta Agricultural Research Center, Ethiopian Institute of \\ Agricultural Research, Addis Ababa, Ethiopia
}

\begin{abstract}
The use of low quality soybean seed is a major limiting factor for yield reduction under tropical and subtropical conditions. Field experiment was carried out at Assosa Agricultural Research Center to determine the effect of priming on yield and yield components of soybean varieties. The experiment had three varieties (Belessa95, Wello and Gishama), three priming types [ $\mathrm{GA}_{3}(100 \mathrm{PPM}), \mathrm{KH}_{2} \mathrm{PO}_{4}(50 \mathrm{PP})$ and water] and three priming durations $(0$, $6,12 \mathrm{hr}$ ) were evaluated using a randomized complete block design (RCBD) in four replications. Highly significant $(\mathrm{P} \leq 0.01)$ difference between interaction of varieties by, priming type and soaking durations for plant height at maturity, number of pods per plants, number of primary branches per plants, yield per hectare, and Varieties by priming type interaction showed highly significant $(\mathrm{P} \leq 0.01)$ difference for day to $50 \%$ flowering, plant height at maturity, number of pods per plants, number of primary branches per plants, harvest index, thousand seed weight and significant $(\mathrm{P} \leq 0.05)$ for number of seed per pod and stand count at harvest. The tallest plant height $(87.26 \mathrm{~cm})$ was recorded when Belessa95 primed with water for $12 \mathrm{hr}$. Also highest number of pods per plant (46) was observed on Belessa 95 primed with $\mathrm{KH}_{2} \mathrm{PO}_{4}$ for $12 \mathrm{hr}$, the highest number of seeds per pods (3) was observed when Wello primed with water and highest yield $(3418.85 \mathrm{Kg})$ was recorded for Wello primed with water for $6 \mathrm{hr}$ and highest stand count at harvest (119.67) was recorded for Wello primed with water. Hence, Water priming was recommended to user to overcome the problems of poor crop emergence and establishments under this adverse environmental condition.
\end{abstract}

Keywords: Chemo-priming, Soybean Varieties, Correlation, Germination.

DOI: $10.7176 / \mathrm{JNSR} / 10-11-05$

Publication date:June 30th 2020

\section{Introduction}

Soybean [Glycine $\max (\mathrm{L}$.$) Merrill] is a legume crop taxonomically belongs to the family leguminace, sub family$ Papilionaceae, tribe phaseolae, Genus Glycine and subgenus Soja (Lackey, 1977). Moreover, the Genus Glycine contains two subgenera, namely Glycine and Soja. The wild (G. soja) and cultivated (G. max) annual species are grouped under thesubgenus Soja. However, the chromosome number of the cultivated soybean species is adiploid tetraploid $(2 \mathrm{n}=2 \mathrm{x}=40)$. The cultivated species; Glycine $\max (\mathrm{L}$.) has never been found in the wild, therefore its probable ancestor is G. soja which is the major gene sources (Hymowitz, 1970). Soybean is considered either a short or a day neutral plant requires 25 to $30^{\circ} \mathrm{C}$ temperature for growth and proper nodulation. Soybean is a medium altitude crop well adapted to altitude varying from 1300 to 1800 masl receiving annual rainfall of 900 to $1300 \mathrm{~mm}$ and it also well at 1900 masl having 550 to $700 \mathrm{~mm}$ annual rainfall (Amare, 1987). The crop has a wide range of soil adaptation, but performs well on light textured, loams and medium black clays with $\mathrm{pH}$ range of 6.5 to 7 in Ethiopia (IAR, 1982).

In 2015, about 318.8 million metric tons of soybeans were produced in the world. The United States of America accounted for about $33.55 \%$ of the soybean production. The other major producers are Brazil $(31.36 \%)$, Argentina (17.88\%), China (3.76\%), Canada (1.96\%) and others account the rest (11.48\%) (USDA, 2016).It is cultivated in Sub-Saharan Africa to a very limited extent (Laswai et al., 2005; Shurtleff and Aoyagi, 2007). During the last decade or so, the African continent accounted for $0.4 \%$ to $0.6 \%$ of the world's total production of soybean, the main producers being Nigeria, SouthAfrica, Zimbabwe and Rwanda. Overall, 19 African countries appear in the world soybean production. More than $90 \%$ of the soybean is produced by Nigeria (48.9\%), Uganda (16.8\%),South Africa (14.9\%), Zimbabwe (8.4\%), Ethiopia (2.7\%) and Rwanda (2.0\%) etc. (Thomas and Erostus, 2008). The economic viability of soybean is determined by commercial utilization of both sub products; oil, and meal, which accounts one and two third of the crop economic value, respectively. Soybean oil is dominant in the world market, accounts about $30 \%$ of the total vegetable oils. In global market, its oil share is estimated nearly $44 \%$, and ranked first among the major oil crops such as rapeseed, groundnut, and sesame (Chung and Singh, 2008). Moreover, on the weight basis, soybean protein yield is about twice, four, and twelve times than that of the meat, eggs, and milk, respectively (Anon., 1984). The nutritional value of soybean primarily lies in its quality protein and oil content which is free of cholesterol (Antalina et al., 1999). The crop is a promising pulse proposed for alleviation of acute protein and oil shortage in the world. Soybean is also nutritious and healthy due to proportional composition of carbohydrate, fiber, vitamins, and minerals (Carter and Wilson, 1998). Studies had been showed a reduced risk of cancer, heart, and chronic disease in soybean product consumed populations (Carter 
and Wilson, 1998). The crop is also highly important in cropping system thereby enriching soil fertility through biological $\mathrm{N}$ fixation in symbiosis with bacteria better than other legume crops. On the average soybean can fix over $75 \mathrm{~kg}$ nitrogen per hectare (LaRue and Patterson, 1981).

The success of the soybean industry is attributed to the crop's agronomic performance and composition (Liu, 2000). Soybean can be grown in a wide range of environments, has moderate drought tolerance, and does not require nitrogen fertilization because of symbiosis with the nitrogen fixing bacteria; Rhizobium. Roughly $60 \%$ of the dry weight of soybean seed is composed of protein and oil, and as a result soybean seed has the highest protein and second highest oil content among cereal and legume species (Liu, 1997). These facts make soybean an important crop for oil manufacturing, animal feed, and food production (Hymowitz et al., 1972; Wilcox and Shibles, 2001). Soybean is important because of its nutritional qualities. It has high percentage of high quality and cheap protein and is a rich source of edible oil. The world production of edible oils consists of $30 \%$ soybean (Assefa, 2008). Soybean seed contains about 40-45\% protein and 20-22\% oil, 20-26\% carbohydrate and a high amount of Ca, P and vitamins (Rahman et al., 2011). In Ethiopia, soybean was started in 1950's on introduced genotypes with main emphasis of identifying adapted lines for the potential areas, replacing imported soybean flour, introducing into the existing cropping systems, and diet of the poor farmers (Amare, 1987). It is a crop that can play major role as protein source for resource poor farmers of Ethiopia who cannot afford animal products. In our country, now a day's soybean is highly utilized in nutrition industries for both food and feeds. According to CSA (2015) the area under soybean cultivation in Ethiopia is estimated about 35259.76 hectares (ha) and 72183.75 tons of production with the productivity of 2.04 tons ha-1 which is by far lower than the world's average of 2.34.0 tons ha- 1 and in Benishangul-Gumuz Region the area under soybean cultivation is 12939.90 hectares and productivity is 1.90 tons ha ${ }^{-1}$ (Masuda and Goldsmith, 2008). Soybean was introduced into Benishangul -Gumuz during resettlement program. Since then, the farmers grow soybean on small scale as sole crop primarily for its economic merit and home consumption. In Assosa zone, soybean was the most dominant pulse crop with the total production area and productivity of 3617.63 ha and 1.46 tons/ha, respectively (CSA, 2015). Now a day's, soybean production is highly raised in the region due to increased demand of the farmers and investors.

Even if the region is suitable for production the use of soybean seeds of low physical and physiological quality is a common practice under this environment, leading to inadequate plant population which final reduce the production and productivity in the field. Faster germination and emergence is an important factor for better, more and uniform stand establishment. This poor crop emergence and establishments might happened due to unpredictable and erratic rain fall, low or inadequate soil nutrients, low quality seeds, hard seed coat, sowing time, low moisture contents of the soil, heat stress, limited access to mechanization and diseases of the crops like soybeans which are mainly grown under such environments all contribute to failures and poor crop stand establishment that may survive the crop poorly under such adverse environmental conditions. Under such conditions seed germinations, seed emergence and seedling establishments can be inhibited and reduced. Therefore, seed priming (seed invigoration) before seed sowing has been a best solution to overcome such adverse environmental effects for better, more and uniform seed germination, seed emergence and seedling establishment. Concerning priming treatments studies on soybean are not adequate but encouraged so more information is required to use this technology in seed production.

Hence, objectives of this study were:-

$>$ To determine the effect of priming on yield and yield components of soybean varieties.

\section{Materials and methods}

\subsection{Description of the Study Sites}

The field experiment was conducted in Benishangul-Gumuz Regional State, at Asossa Agricultural Research Center (AARC) on station in the 2015 main cropping season under rain fed field conditions. Benishangul- Gumuz Regional State is geographically located at the latitude of $9^{0} 30^{\prime}$ to $11^{0} 39^{\prime \prime} \mathrm{N}$ and longitude of $34^{0} 20^{\prime}$ to $36^{0} 30^{\prime \prime} \mathrm{E}$ covering a total land area of 50,000 square kilometer. The study site is located at $10^{\circ} 02^{\prime} 05^{\prime \prime} \mathrm{N}$ latitude and $34^{0} 34^{\prime}$ 09" E longitudes and situated east of Assosa town and west of Addis Ababa about $14 \mathrm{~km}$ and $653 \mathrm{~km}$ distance, respectively. The area experiences a unimodal rainfall pattern and has annual rainfall of about $1118 \mathrm{~mm}$ out of which $936.3 \mathrm{~mm}$ rain was recorded during the growing season of the crop. The rainy season occurs from March to December and the maximum rain is received in August. The minimum and maximum temperatures are $11.9^{\circ} \mathrm{C}$ and $32.7^{\circ} \mathrm{C}$, respectively. The soil type of the area is Nitosol which is dark reddish brown to dark red in colour and the crops mainly cultivated in the area are sorghum, maize, soybean and finger millet (AARC, 2007).

\subsection{Treatments and Experimental Design}

The treatments consist of three varieties of soybean namely Belessa- 95, Wello and Gishama and priming treatments $\mathrm{GA}_{3}(100 \mathrm{PPM}), \mathrm{KH}_{2} \mathrm{PO}_{4}(50 \mathrm{PPM})$ and water at timings of 0,6 and $12 \mathrm{hr}$. The size of each plot was $4 \times 3 \mathrm{~m}$ $\left(12 \mathrm{~m}^{2}\right)$. The space between blocks was $1 \mathrm{~m}$, the space between rows in each plot was $60 \mathrm{~cm}$ and spacing between plants was $5 \mathrm{~cm}$. The rate of fertilizer used was $100 \mathrm{~kg}$ DAP which contains $18 \% \mathrm{~N}$ and $46 \% \mathrm{P}_{2} \mathrm{O}_{5}$ as a source of 
Nitrogen and Phosphorus. The experiment was laid out in factorial arrangement using Randomized Complete Block Design (RCBD) in four replications.

\subsection{Experimental Procedure and Field Management}

The land was prepared for planting by tractor, disked and harrowed. The seeds of all the three varieties were soaked in $\mathrm{GA}_{3}(100 \mathrm{PPM}), \mathrm{KH}_{2} \mathrm{PO}_{4}(50 \mathrm{PPM})$ and water for 0,6 and $12 \mathrm{hr}$. The seeds of all the varieties were used as control where Hydro priming and osmo priming treatments were not applied. After giving treatment for 0, 6and 12 hours the seed was removed from water and solutions then it was kept in filter paper to remove the remaining solution. All the primed seeds were again re-dried at room temperature until they gain their original seed moisture content. Seed was sown in last week of June 2015 in rows by placing the seeds at an appropriate distance as per the treatments with the help of tape meter and then covered it manually with the soil. All cultural practices such as weeding fertilizer application etc were applied uniformly to all plants. The crop was harvested manually when the crop reached physiological maturity and sun dried for up to 14 days to adjust the moisture contents of the seed to $10 \%$.

\subsection{Data Collected}

\subsubsection{Growth phenology, yield component and yield}

Days to 50\% flowering: The number of days taken from the date of sowing to flowering were calculated and expressed in number as days taken for 50 per cent of plants showed flowers.

Plant height: The plant height on five randomly selected and tagged plants were measured from the base of the plant to the tip of the shoot apex at physiological maturity and the average height of five plants was worked out and expressed in centimeters.

Days to Physiological maturity: were recorded as the number of days from sowing to $90 \%$ plants per plot attains maturity (the seed as well as pod turn yellow).

Number of pods per plant: The number of pods from five randomly selected and tagged plants and average was taken.

Number of seeds per pod: The number of seeds per plant was counted from five randomly selected plants and the average was taken.

Number of Primary branches per plant: The number of primary branches on the main stem per plant harvested at maturity was obtained by counting the branches from five randomly selected and average was taken.

Stand count at harvest: the number of plants per net plot at harvest.

Harvest index was determined as the ratio of grain yield to the total above ground dry biomass yield.

Thousand seed weight: determined by weighing 1000 seeds sampled from each plot using an electronic sensitive balance.

Yield per hectare: The matured pods harvested from the net plot in each treatment were sun dried and the seed was separated. The weight of the seeds harvested from net plot area was recorded and converted to yield per hectare after adjusting to $10 \%$ moisture content.

\subsection{Data Analysis}

Data were subjected to Analysis of Variance (ANOVA) using Gomez and Gomez (1984) with computer software SAS statistical package, Version 9.1 (SAS, 2000). Whenever the effects of the factors were found to be significant, the means were compared using the Tukey's Studentized Range (HSD) test at 5\% level of significance.

\section{Results and discussions}

\subsection{Field Experiment}

\subsubsection{Days to $50 \%$ flowering}

There was a highly significant $(\mathrm{P} \leq 0.01)$ difference among varieties, seed priming type and their interaction effect for days to 50 per cent flowering. Wello(2)variety which is primed with $\mathrm{GA}_{3}(\mathrm{~B})$ took significantly lesser days (82) to 50 per cent flowering followed by wello $(2)$ primed with $\mathrm{KH}_{2} \mathrm{PO}_{4}(\mathrm{C})$ and unprimed $(\mathrm{A})$ Wello variety which took (85.33) days to 50per cent flowering. Significantly delayed flowering was exhibited on unprimed (A) Belessa95 (1) variety which took (93days) and was at par with Belessa 95(1) variety primed with $\mathrm{GA}_{3}(\mathrm{~B})$ and $\mathrm{KH}_{2} \mathrm{PO}_{4}(\mathrm{C})$ which took (91days) whereas the other combination showed an intermediate values (Table1). The results agreed with Khairul, et al.(2015) who reported that chickpea seed primed with $\mathrm{GA}_{3}$ took minimum number of (70) compared to hydro primed chickpea seed which took (82.33) days to 50\% flowering. Similarly, Punjabi et al. (1992)reported that soybean variety applied with $\mathrm{GA}_{3}(100 \mathrm{ppm})$ initiated flowering and increased number of flower per plants (35.44) as compared to control (16.78). On the other hand, Harris et al. (2007) found that the priming in maize led to better crop establishment and growth, earlier flowering and greater yields. The accelerated flowering in case of $\mathrm{GA}_{3}$ might be due to their effect in the fast emergence of the seeds at the beginning and the variation in case of the three different unprimed soybean varieties might be due to early and late flowering of the varieties. In addition to better establishment, farmers reported that primed crops grew more vigorously, flowered 
earlier and yielded higher (Farooq et al., 2008).

Table 1.Interaction effects of Soybean varieties and priming types on days to 50\% flowering, number of seed per pod, stand count at harvest, harvest index and thousand seed weight.

\begin{tabular}{|c|c|c|c|c|c|}
\hline Interaction & $\mathrm{D} 50 \% \mathrm{~F}$ & NSPP & SCAH & $\mathrm{HI}$ & $1000 \mathrm{SW}$ \\
\hline $1 \mathrm{~A}$ & $93.00^{\mathrm{a}}$ & $2.47^{\mathrm{fg}}$ & $116.67^{\text {ghi }}$ & $31.00^{\mathrm{a}}$ & $150.00^{\text {cdef }}$ \\
\hline $1 \mathrm{~B}$ & $91.00^{\mathrm{b}}$ & $2.87^{\mathrm{abc}}$ & $119.44^{\mathrm{ab}}$ & $27.00^{\mathrm{cd}}$ & $157.20^{\text {abcde }}$ \\
\hline $1 \mathrm{C}$ & $91.00^{\mathrm{b}}$ & $2.87^{\mathrm{abc}}$ & $118.67^{\mathrm{bcd}}$ & $27.00^{\mathrm{cd}}$ & $145^{\text {efghi }}$ \\
\hline $1 \mathrm{D}$ & $90.00^{\mathrm{bc}}$ & $2.93^{\mathrm{ab}}$ & $120.00^{\mathrm{a}}$ & $25.00^{\mathrm{de}}$ & $152.80^{\text {bcdef }}$ \\
\hline $2 \mathrm{~A}$ & $85.33^{f}$ & $2.53^{\text {efg }}$ & $117.33^{\mathrm{efgh}}$ & $27.00^{\mathrm{cd}}$ & $140.00^{\mathrm{ghi}}$ \\
\hline $2 \mathrm{~B}$ & $82.00^{\mathrm{g}}$ & $2.8 .00^{\mathrm{abcd}}$ & $119.33^{\mathrm{ab}}$ & $23.00^{\mathrm{de}}$ & $136.70^{\mathrm{hi}}$ \\
\hline $2 \mathrm{C}$ & $85.33^{\mathrm{f}}$ & $3.00^{\mathrm{a}}$ & $118.67^{\mathrm{bcd}}$ & $30.00^{\mathrm{ab}}$ & $146.10^{\text {efghi }}$ \\
\hline $2 \mathrm{D}$ & $87.00^{\mathrm{ef}}$ & $3.00^{\mathrm{a}}$ & $119.67^{\mathrm{ab}}$ & $27.00^{\text {bcd }}$ & $153.10^{\text {bcdef }}$ \\
\hline $3 \mathrm{~A}$ & $90.00^{\mathrm{bc}}$ & $2.33^{\mathrm{g}}$ & $116.00^{\mathrm{i}}$ & $31.00^{\mathrm{a}}$ & $148.30^{\mathrm{defgh}}$ \\
\hline $3 \mathrm{~B}$ & $87.33^{\mathrm{de}}$ & $2.73^{\text {bcde }}$ & $117.33^{\mathrm{efgh}}$ & $27.00^{\mathrm{cd}}$ & $155.00^{\text {abcdef }}$ \\
\hline $3 \mathrm{C}$ & $89.00^{\text {cd }}$ & $2.71^{\text {bcde }}$ & $117.00^{\text {fghi }}$ & $28.00^{\mathrm{abcd}}$ & $163.90^{\mathrm{ab}}$ \\
\hline $3 \mathrm{D}$ & $89.00^{\mathrm{cd}}$ & $2.6^{\mathrm{def}}$ & $118.67^{\mathrm{bcd}}$ & $30.00^{\mathrm{abc}}$ & $166.30^{\mathrm{a}}$ \\
\hline LSD & 1.85 & 0.22 & 1.21 & 2.40 & 11.80 \\
\hline CV & 1.24 & 4.71 & 4.62 & 4.76 & 5.74 \\
\hline
\end{tabular}

Where, $\mathrm{D} 50 \% \mathrm{~F}=$ Day to $50 \%$ flowering, $\mathrm{NSPP}=$ Number of seed per plant, $\mathrm{SCAH}=$ Stand count at harvest, $\mathrm{HI}=$ harvest index, 1000SW $=$ Thousand seed weight $1=$ Belessa 95, $2=$ Wello, $3=$ Gishema, $\mathrm{A}=$ Control $\mathrm{B}=$ Gibberellic acid, $\mathrm{C}=$ Potassium dihydrophosphate and $\mathrm{D}=$ Water. Means followed by the same letter(s) at each column and row are not significantly different from each other at 0.05 level of probability.

\subsubsection{Plant height}

There was a highly significant $(\mathrm{P} \leq 0.01)$ difference among varieties, duration of priming, seed priming type and interaction effect for plant height at maturity. The tallest plant height was recorded for Belessa 95 variety $(87.27 \mathrm{~cm})$ hydro primed for 12 hour which was at par with Gishama hydro primed for $6 \mathrm{hr}(86.57 \mathrm{~cm})$ and for $12 \mathrm{hr}(85.23 \mathrm{~cm})$ (Table2).Gishama variety which was primed with $\mathrm{GA}_{3}$ for 0,12 and 6 hours has also the highest plant height $(84.54 \mathrm{~cm}),(83.80 \mathrm{~cm})$ and $(83.67 \mathrm{~cm})$ respectively. This result was agreed with Punjabi et al. (1992) who reported that Soybean seed primed with $\mathrm{GA}_{3}(100 \mathrm{ppm})$ records the tallest plant height $(57.10 \mathrm{~cm})$ as compared to control $(25.11 \mathrm{~cm})$.This might be due to the importance of priming treatments for stimulations of genes that are important for enhancement of cell division which leads to increase plant height at maturity. Basically, plant height is a genetically controlled character, but several studies have indicated that the plant height can be increased or decreased by different seed quality enhancement practices Ali, (2009).The beneficial effect of exogenous application of $\mathrm{GA}_{3}$ to seeds might be due to the translocation of $\mathrm{GA}_{3}$ to the aerial part of plants, and this perhaps occurs to an extent that is enough to increase hypocotyls size and the consequent increase in first node height hence sufficient to positively affect plant height (Chavan et al.,2014)

Bensen et al. (1990), demonstrate the hypocotyls growth rate is directly associated with the amount of $\mathrm{GA}_{3}$.Belessa 95 variety which was primed with $\mathrm{KH}_{2} \mathrm{PO} 4$ for $12 \mathrm{hr}$ records $(79.4 \mathrm{~cm})$ plant height which is at par with Wello and Belessa 95 variety primed with $\mathrm{KH}_{2} \mathrm{PO} 4$ for $12 \mathrm{hr}$ which records $(79.2 \mathrm{~cm})$ and $(79.4 \mathrm{~cm})$ respectively. The result is in agreement with Mohammadi(2009) who reported that soybean seed primed with potassium nitrate showed the highest plant height( $43.4 \%)$ as compared to control. The enhanced plant height may also be due to the improved and faster plant emergence in $\mathrm{GA}_{3}$, Water and $\mathrm{KH}_{2} \mathrm{PO}_{4}$ primed varieties which created cooperative competition among the plants for light and resulted in taller plants. The results agree with Harris et al. (2000) who reported that seed priming of ten rice varieties resulted in taller plants $(108 \mathrm{~cm}$ and $94 \mathrm{~cm})$ in two years. The shortest plant height was observed on the unprimed Wello variety $(68.13 \mathrm{~cm})$, Belessa 95 variety $(72 \mathrm{~cm})$, Wello primed with $\mathrm{GA}_{3}$ for $0 \mathrm{hr}(72.20 \mathrm{~cm})$ which is at par with Wello primed with $\mathrm{KH}_{2} \mathrm{PO}_{4}$ for $0 \mathrm{hr}(73.20 \mathrm{~cm})$ and Wello primed with $\mathrm{GA}_{3}$ for $0 \mathrm{hr}(73.72 \mathrm{~cm})$. 
Table 2.Interaction effects of priming, soaking duration and varieties on Plant height

\begin{tabular}{|c|c|c|c|c|}
\hline \multirow{2}{*}{ Variety } & \multirow{2}{*}{ PT } & \multicolumn{3}{|c|}{ Priming durations } \\
\hline & & 0 & 6 & 12 \\
\hline \multirow[t]{4}{*}{ Belessa 95} & $\mathrm{GA}_{3}$ & $76.40^{\text {efghi }}$ & $74.07^{\text {fghi }}$ & $76.73^{\text {efghi }}$ \\
\hline & $\mathrm{KH}_{2} \mathrm{PO} 4$ & $75.20^{\text {fghi }}$ & $75.00^{\text {fghi }}$ & $79.40^{\text {cdef }}$ \\
\hline & Water & $75.88^{\text {efghi }}$ & $81.33^{\text {bcde }}$ & $87.27^{\mathrm{a}}$ \\
\hline & Control & $72.00^{\mathrm{ij}}$ & $72.00^{\mathrm{ij}}$ & $72.00^{\mathrm{ij}}$ \\
\hline \multirow[t]{4}{*}{ Gishema } & $\mathrm{GA}_{3}$ & $84.54^{\mathrm{abc}}$ & $83.67^{\mathrm{abcd}}$ & $83.80^{\mathrm{abcd}}$ \\
\hline & $\mathrm{KH}_{2} \mathrm{PO} 4$ & $73.27^{\text {ghij }}$ & $75.32^{\text {fghi }}$ & $76.33^{\text {efghi }}$ \\
\hline & Water & $76.33^{\text {efghi }}$ & $86.57^{\mathrm{ab}}$ & $85.23^{\mathrm{ab}}$ \\
\hline & Control & $74.47^{\text {fghi }}$ & $74.47^{\text {fghi }}$ & $74.47^{\text {fghi }}$ \\
\hline \multirow[t]{4}{*}{ Wello } & $\mathrm{GA}_{3}$ & $72.20^{\mathrm{hij}}$ & $74.67^{\text {fghi }}$ & $73.78^{\text {fghij }}$ \\
\hline & $\mathrm{KH}_{2} \mathrm{PO} 4$ & $73.20^{\text {ghij }}$ & $75.68^{\text {efghi }}$ & $79.20^{\text {cdef }}$ \\
\hline & Water & $73.72^{\text {fghij }}$ & $78.13^{\mathrm{defg}}$ & $77.87^{\mathrm{efgh}}$ \\
\hline & Control & $68.13^{\mathrm{j}}$ & $68.13^{\mathrm{j}}$ & $68.13^{\mathrm{j}}$ \\
\hline LSD & 5.78 & & & \\
\hline $\mathrm{CV}$ & 2.32 & & & \\
\hline
\end{tabular}

Where, $\mathrm{PT}=$ Priming typeGA $\mathrm{G}_{3}=$ Gibberellic acid, $\mathrm{KH}_{2} \mathrm{PO}_{4}=$ Potassium dihydrophosphate. Means followed by the same letter(s) at each column and row are not significantly different from each other at 0.05 level of probability.

\subsubsection{Physiological maturity}

There was a highly significant difference among varieties and significant $(\mathrm{P} \leq 0.05)$ difference among priming types for hastening Physiological maturity. Among variety Wello variety took significantly lesser days (120.8) to Physiological maturity as compared to Belessa 95 and Gishama which took (123.2) and (125) days respectively(Table3). Among priming types there was significance Soybean varieties which was primed with $\mathrm{GA}_{3}$ took significantly lesser days (122) to Physiological maturity compared to Water and $\mathrm{KH}_{2} \mathrm{PO}_{4}$ which took (123.11) and (123.56) days respectively (Table3) this might be due to the faster germination of seed as the results of gibberallic whereas the variation between varieties to accelerated or delayed physiological maturity might be due to genetic variations among them.

Table 3.Main effect of priming types and soybean varieties on physiological maturity.

\begin{tabular}{ll}
\hline Variety & physiological maturity \\
\hline Gishema & $125.00^{\mathrm{a}}$ \\
Belessa & $123.20^{\mathrm{b}}$ \\
Wello & $120.80^{\mathrm{c}}$ \\
\hline LSD $(0.05)$ & 0.53 \\
\hline Priming type & \\
\hline $\mathrm{GA}_{3}$ & $122.00^{\mathrm{b}}$ \\
$\mathrm{KH}_{2} \mathrm{PO}_{4}$ & $123.56^{\mathrm{a}}$ \\
Water & $123.11^{\mathrm{a}}$ \\
\hline LSD $(0.05)$ & 0.94 \\
\hline CV $(\%)$ & 0.80 \\
\hline
\end{tabular}

Where, $\mathrm{GA}_{3}=$ Gibberellic acid, $\mathrm{KH}_{2} \mathrm{PO}_{4}=$ Potassium dihydrophosphate. Means followed by the same letter(s) at each column and row are not significantly different from each other at 0.05 level of probability.

3.1.4. Number of pods per plant:

There was a highly significant $(\mathrm{P} \leq 0.01)$ difference among varieties, priming type, priming durations and their interactions for number of pods per plant. The highest number of pods per plant was observed on Belessa 95 variety primed with $\mathrm{KH}_{2} \mathrm{PO}_{4}$ for $12 \mathrm{hr}(46.00)$ and $6 \mathrm{hr}(45.33)$ followed by Wello variety primed with $\mathrm{KH}_{2} \mathrm{PO} 4$ for $12 \mathrm{hr}$ (45.13) and $6 \mathrm{hr}$ (44.87) whereas the lowest number of pods per plant was observed for Gishema varieties primed with $\mathrm{GA}_{3}$ for $0 \mathrm{hr}$ (22.73), unprimed Belessa 95 (30.27),Wello(31.40)and Gishema (24) varieties (Table 4). These results are similar with the finding of Shahram (2015) who reported that soybean seed primed with $\mathrm{KH}_{2} \mathrm{PO}_{4}$ and water records (132.8) and (124.5) number of pods per plant respectively compared to control (85.91). Similarly, Mohammadi (2009) reported that soybean seed primed with potassium nitrate showed the highest value of number of pods per plant (56.5\%) as compared to control. Wello variety primed with $\mathrm{GA}_{3}$ for $12 \mathrm{hr}$ gave 43.53 pods per plant which was at par with Belessa 95 primed with water for $12 \mathrm{hr}(43.20)$ and $6 \mathrm{hr}(41.93)$ and Wello variety primed with water for $12 \mathrm{hr}(41.27)$ and $6 \mathrm{hr}$ (40.40) (Table 4). These results are in line with the report of (Khairul, et al.,2015) who reports that chickpea seed primed with $\mathrm{GA}_{3} 225 \mathrm{ppm}$ and $\mathrm{GA}_{3} 300 \mathrm{ppm}$ resulted in (55.50) and (52.38) number of pods per plants respectively compared to hydro primed chickpea seeds. Similarly, Aldesuquy and Ibrahim (2000) reported that the seed treatment with shikimic acid improved yield and yield components of cowpea plants by increasing the number of pods per plant and number of seeds per pod. 
Table 4 .Interaction effects of priming types, durations and varieties on number of pods per plant.

\begin{tabular}{|c|c|c|c|c|}
\hline \multirow{2}{*}{ Variety } & \multirow{2}{*}{ PT } & \multicolumn{3}{|c|}{ Priming durations } \\
\hline & & 0 & 6 & 12 \\
\hline \multirow[t]{4}{*}{ Belessa 95} & $\mathrm{GA}_{3}$ & $36.53^{\text {bcdefgh }}$ & $35.33^{\text {cdefghi }}$ & $35.60^{\text {cdefghi }}$ \\
\hline & $\mathrm{KH}_{2} \mathrm{PO} 4$ & $33.33^{\text {defghij }}$ & $45.33^{\mathrm{ab}}$ & $46.00^{\mathrm{a}}$ \\
\hline & Water & $32.13^{\text {fghijk }}$ & $41.93^{\mathrm{abcd}}$ & $43.20^{\mathrm{abc}}$ \\
\hline & Control & $30.27^{\mathrm{hijklm}}$ & $30.27^{\text {hijklm }}$ & $30.27^{\mathrm{hijklm}}$ \\
\hline \multirow[t]{4}{*}{ Gishema } & $\mathrm{GA}_{3}$ & $22.73^{\mathrm{m}}$ & $26.73^{\mathrm{ijklm}}$ & $27.20^{\mathrm{ijklm}}$ \\
\hline & $\mathrm{KH}_{2} \mathrm{PO} 4$ & $23.471 \mathrm{~m}$ & $27.60^{\mathrm{ijklm}}$ & $30.27^{\mathrm{hijklm}}$ \\
\hline & Water & $24.27^{\mathrm{klm}}$ & $26.07^{\mathrm{jklm}}$ & $26.07^{\mathrm{jklm}}$ \\
\hline & Control & $24.00^{\mathrm{klm}}$ & $24.00^{\mathrm{klm}}$ & $24.00^{\mathrm{klm}}$ \\
\hline \multirow[t]{4}{*}{ Wello } & $\mathrm{GA}_{3}$ & $39.27^{\text {abcdefg }}$ & $37.73^{\text {abcdefgh }}$ & $43.53^{\mathrm{abc}}$ \\
\hline & $\mathrm{KH}_{2} \mathrm{PO} 4$ & $34.87^{\text {cdefghij }}$ & $44.87^{\mathrm{ab}}$ & $45.13^{\mathrm{ab}}$ \\
\hline & Water & $32.67^{\text {efghijk }}$ & $40.40^{\text {abcdef }}$ & $41.27^{\mathrm{abcd}}$ \\
\hline & Control & $31.40^{\text {ghijklm }}$ & $31.40^{\text {ghijklm }}$ & $31.40^{\text {ghijklm }}$ \\
\hline LSD & 8.92 & & & \\
\hline $\mathrm{CV}$ & 8.05 & & & \\
\hline
\end{tabular}

Where, $\mathrm{PT}=$ Priming types $\mathrm{GA}_{3}=$ Gibberellic acid, $\mathrm{KH}_{2} \mathrm{PO}_{4}=$ Potassium dihydrophosphate. Means followed by the same letter(s) at each column and row are not significantly different from each other at 0.05 level of probability.

\subsubsection{Number of seeds per pod}

There was highly significance difference among varieties $(\mathrm{P} \leq 0.01)$ and significant interaction $(\mathrm{P} \leq 0.05)$ effect between varieties by priming type for number of seeds per pod. The highest number of seed per pod was recorded on Wello(2) variety primed with $\mathrm{KH}_{2} \mathrm{PO}_{4}(\mathrm{C})(3)$ and water(D) (3) which are at par with Belessa 95(1)variety primed with water(D)(2.93), with $\mathrm{KH}_{2} \mathrm{PO}_{4}(\mathrm{C})(2.87)$, withGA $3(\mathrm{~B})(2.87)$ and Wello(2) variety primed withGA $3(\mathrm{~B})(2.8)$. (Table 2). The three unprimed (A) soybean varieties show the lower number of seeds per pod Gishema (3) (2.33), Belessa95 (1) (2.47) and Wello(2) (2.47) compared to the primed soybean varieties (Table 1).These results are similar with the report of Mohammadi (2009) who reported that soybean seed primed with potassium nitrate showed the highest number of seeds per pod (23.8\%) as compared to control. Similarly, Shahram (2015) reported that soybean seed primed with water and $\mathrm{KH}_{2} \mathrm{PO}_{4}$ gave the same seed number seed per pods which is $(2.59)$ and (2.52) respectively compared to control (1.94). Similarly, results were also reported by Rashid et al. (2004) in mungbean reported that the primed seed plants produced more seed per pod.

\subsubsection{Number of Primary branches per plant}

There was highly significance difference $(\mathrm{P} \leq 0.01)$ among varieties, priming type, durations of priming and their interaction effect on number of primary branches per plant. The highest number of primary branches per plant was observed on Wello and Belessa95variety primed with $\mathrm{KH}_{2} \mathrm{PO}_{4}$ for $12 \mathrm{hr}(6.60)$ and for $6 \mathrm{hr}(6.54)$ respectively which was at par with Gishema and Belessa95 primed with $\mathrm{KH}_{2} \mathrm{PO}_{4}$ for $12 \mathrm{hr}(6.53)$ and for $6 \mathrm{hr}$ (6.47) respectively. Similarly, the highest number of primary branches per plant was also observed on hydro primed Belessa95variety for $6 \mathrm{hr}$ (6.47) and for $12 \mathrm{hr}$ (6.27) and Gishema hydro primed for $6 \mathrm{hr}$ (6.40) and for $12 \mathrm{hr}(6.13)$. The lowest number of primary branches per plant was recorded on Gishema variety primed with $\mathrm{GA}_{3}$ for $6 \mathrm{hr}(2.47)$ whereas the other showed an intermediate value (Table 5). Unprimed soybean varieties gave lower number of primary branches per plant. The results are in agreement with those obtained by Kaur et al. (2002) who reported that primed chickpea seeds increased number of branches 30-40\% than unprimed seeds. Similarly, Punjabi et al.(1992) found that Soybean seed primed with $\mathrm{GA}_{3}(100 \mathrm{ppm})$ records the highest number of branches per plant (5.11) as compared to control (3.89). The variation in the number of branches might be due to the vigorous growth of the plants due to the priming effects. 
Table 5.Interaction effects of priming types, duration and varieties on number of primary branches per plant.

\begin{tabular}{|c|c|c|c|c|}
\hline \multirow{2}{*}{ Variety } & \multirow{2}{*}{ PT } & \multicolumn{3}{|c|}{ Priming durations } \\
\hline & & 0 & 6 & 12 \\
\hline \multirow[t]{4}{*}{ Belessa 95} & $\mathrm{GA}_{3}$ & $3.27^{\mathrm{bcd}}$ & $3.87^{\mathrm{bc}}$ & $3.33^{\mathrm{bcd}}$ \\
\hline & $\mathrm{KH}_{2} \mathrm{PO} 4$ & $3.53^{\mathrm{bcd}}$ & $6.54^{\mathrm{a}}$ & $6.22^{\mathrm{a}}$ \\
\hline & Water & $3.40^{\mathrm{bcd}}$ & $6.47^{\mathrm{a}}$ & $6.27^{\mathrm{a}}$ \\
\hline & Control & $2.87^{\mathrm{bcd}}$ & $2.87^{\mathrm{bcd}}$ & $2.87^{\mathrm{bcd}}$ \\
\hline \multirow[t]{4}{*}{ Gishema } & $\mathrm{GA}_{3}$ & $2.73^{\mathrm{cd}}$ & $2.47^{\mathrm{d}}$ & $3.00^{\mathrm{bcd}}$ \\
\hline & $\mathrm{KH}_{2} \mathrm{PO} 4$ & $3.07^{\mathrm{bcd}}$ & $6.47^{\mathrm{a}}$ & $6.53^{\mathrm{a}}$ \\
\hline & Water & $3.67^{\mathrm{bcd}}$ & $6.40^{\mathrm{a}}$ & $6.13^{\mathrm{a}}$ \\
\hline & Control & $3.07^{\mathrm{bcd}}$ & $3.07^{\mathrm{bcd}}$ & $3.07^{\mathrm{bcd}}$ \\
\hline \multirow[t]{4}{*}{ Wello } & $\mathrm{GA}_{3}$ & $2.87^{\mathrm{bcd}}$ & $4.13^{b}$ & $3.53^{\mathrm{bcd}}$ \\
\hline & $\mathrm{KH}_{2} \mathrm{PO} 4$ & $3.93^{\mathrm{bc}}$ & $6.53^{\mathrm{a}}$ & $6.60^{\mathrm{a}}$ \\
\hline & Water & $2.93^{\mathrm{bcd}}$ & $3.00^{\text {bcd }}$ & $3.13^{\mathrm{bcd}}$ \\
\hline & Control & $2.67^{\mathrm{cd}}$ & $2.67^{\mathrm{cd}}$ & $2.67^{\mathrm{cd}}$ \\
\hline LSD & 1.38 & & & \\
\hline $\mathrm{CV}$ & 9.92 & & & \\
\hline
\end{tabular}

Where, $\mathrm{PT}=$ Priming types $\mathrm{GA}_{3}=$ Gibberellic acid, $\mathrm{KH}_{2} \mathrm{PO}_{4}=$ Potassium dihydrophosphate. Means followed by the same letter(s) at each column and row are not significantly different from each other at 0.05 level of probability.

\subsubsection{Stand count at harvest}

There was a highly significant $(\mathrm{P} \leq 0.01)$ difference due to varieties, priming type and priming duration and significant $(\mathrm{P} \leq 0.05)$ interaction effect between variety and priming type for stand count at harvest. The highest stand count at harvest was recorded for Hydro primed(D)Wello (2) variety (119.67) followed by Belessa95(1) variety primed with $\mathrm{GA}_{3}(\mathrm{~B})(119.44)$ and Wello $(2)$ variety primed with $\mathrm{GA}_{3}(\mathrm{~B})(119.33)$ that was at par with hydro primed (D)Belessa 95(1)variety (119.11),hydro primed (D)Gishema (3)variety (118.67), Belessa 95 (1)and Wello(2) varieties primed with $\mathrm{KH}_{2} \mathrm{PO}_{4}(\mathrm{C})(118)$ and (117.78) respectively. The lowest Stand count at harvest was observed on three of unprimed (A) varieties Wello(2) (117.33) followed by Belessa 95(1) (116.67) and Gishema (3) (116) varieties (Table 1).

\subsubsection{Harvest index}

There was highly significant difference $(\mathrm{P} \leq 0.01)$ among varieties, priming type and between their interactions effects for Harvest index. The highest harvest index was observed on unprimed (A) Belessa 95(1) variety (31) and unprimed (A)Gishema(3)variety (30.67) followed by Wello(2) variety primed withKH $\mathrm{PO}_{4}(\mathrm{C})(30.33)$. Whereas the lowest harvest index was recorded on Wello(2)variety primed withGA $\mathrm{H}_{3}(\mathrm{~B})(21.67)$ followed by unprimed (A) Wello(2) variety (25.67) which were statistically similar results with that of Belessa 95(1) variety primed with $\mathrm{GA}_{3}(\mathrm{~B})(25.78)$ and Gishema(3) variety primed with $\mathrm{GA}_{3}(\mathrm{~B})(25.89)$ (Table 1). The findings are in agreement with Shahram (2015) who reported that soybean seed primed with water and $\mathrm{KH}_{2} \mathrm{PO}_{4}$ records the lowest harvest index (37.32) and (37.60) respectively compared to control which records (40.13) harvest index. It has also been observed that seed priming improved allometric traits, grain yield and harvest index (Ruan et al., 2002)

\subsubsection{Thousand Seed weight}

The result of the study showed that there was a highly significant $(\mathrm{P} \leq 0.01)$ difference between varieties, priming type sand their interaction effects on Thousand Seed weight. The highest hundred seed weight was recorded on Gishema (3)variety primed with water (D) (166.30) followed by Gishema (3)variety primed with $\mathrm{KH}_{2} \mathrm{PO}_{4}(\mathrm{C})$ (163.90) and the lowest hundred seed weight were observed for Wello (2) variety primed with $\mathrm{GA}_{3}(\mathrm{~B})(136.70)$ followed by unprimed(A) Wello (2) variety (140.00). Whereas the other shows intermediate values (Table 1). The results are in agreement with Shahram (2015) who reported that the soybean seed primed with water and $\mathrm{KH}_{2} \mathrm{PO}_{4}$ gave the highest thousand seed weight of (142.23) and (140.33) respectively compared to control(116.37).

\subsubsection{Yield per hectare}

Seed yield is the ultimate output of a crop around which all the other factors revolved. There was highly significance $(\mathrm{P} \leq 0.01)$ difference between varieties, priming type, durations of priming and their interaction effect for increments of yield per hectare. The results are in agreement with Harris et al., (1999) who reported that primed crops produced higher yields than non-primed crops. The highest yield per hectare was recorded on Wello variety primed with water for $6 \mathrm{hr}(3418.85 \mathrm{Kg})$ followed by Wello variety primed with $\mathrm{GA}_{3}$ for $6 \mathrm{hr}(3412.15 \mathrm{Kg})$ that was at par with Wello variety primed with $\mathrm{GA}_{3}$ for $12 \mathrm{hr}(3406.60 \mathrm{Kg})$, for $0 \mathrm{hr}(3329.98 \mathrm{Kg})$ and Wello variety primed with $\mathrm{KH}_{2} \mathrm{PO}_{4}$ for $12 \mathrm{hr}(3395.24 \mathrm{Kg})$ and Wello variety primed with water for $12 \mathrm{hr}(3370.48 \mathrm{Kg})$, for $0 \mathrm{hr}$ $(3297.59 \mathrm{Kg})$ (Table6).

This result are consistent with the findings of Shahram (2015) who reported that soybean seed primed with water significantly increases yield per hectare (4.96ton/ha) compared to seed primed with $\mathrm{KH}_{2} \mathrm{PO} 4$ (4.61ton/ha) and control which records (4.13ton/ha). It was also reported that soybean seed priming made better seedling emergence and yield improvement (Arif et al., 2008).Similarly, Taylor and Harman, (1990) reported that in the 
low external input system of Bihar and West Bengal, in India, primed plots of chickpeas out-yielded non-primed plots in 41 trials with an average yield increase of around 13\%. The lowest yield per hectare was observed on Gishema variety hydro primed for $0 \mathrm{hr}$ (2373.08) and with $\mathrm{GA}_{3}$ for $0 \mathrm{hr}$ (2385.44) that was at par with unprimed Belessa 95 variety(2390.55) and Gishema variety (2392.76).This results are in line with the report of Chavan et al., (2014) who have reported that soybean seed variety primed withGA $3 \mathrm{KH}_{2} \mathrm{PO}_{4}(100 \mathrm{ppm})$ and water gave highest yield per hectare (2954.50),(2892.00)and (2715.00)respectively over the unprimed one(2403.20).(Mewael and Ravihunja (2008) have reported that soybean seeds primed with $\mathrm{CaCl}_{2} .2 \mathrm{H}_{2} \mathrm{O}, \mathrm{GA}_{3}$ and $\mathrm{KH}_{2} \mathrm{PO}_{4}$ recorded $(20.73,17.93,17.15$ and $8.6 \%)$ increment in seed yield per hectare respectively over unprimed seeds. Priming of chickpea seeds has been reported to increase the seed yield (Kaur et al., 2002). Shahram (2015) suggested that hydro-priming is a useful method for improving seedling vigor, establishment and yield of soybean in the field. Table 6.Interaction effects of priming types, duration and varieties on yield per hectare

\begin{tabular}{|c|c|c|c|c|}
\hline \multirow{2}{*}{ Variety } & \multirow{2}{*}{ PT } & \multicolumn{3}{|c|}{ Priming durations } \\
\hline & & 0 & 6 & 12 \\
\hline \multirow[t]{4}{*}{ Belessa 95} & $\mathrm{GA}_{3}$ & $2429.25^{\mathrm{GHIJ}}$ & $2935.77^{\mathrm{CD}}$ & $3009.74^{\mathrm{BC}}$ \\
\hline & $\mathrm{KH}_{2} \mathrm{PO} 4$ & $2627.84^{\mathrm{EFGHI}}$ & $2596.06^{\text {FGHIJ }}$ & $2643.08^{\mathrm{EFGH}}$ \\
\hline & Water & $2427.70^{\mathrm{HIJ}}$ & $2949.04^{\mathrm{CD}}$ & $2983.36^{\mathrm{BC}}$ \\
\hline & Control & $2390.55^{\mathrm{J}}$ & $2390.55^{\mathrm{J}}$ & $2390.55^{\mathrm{J}}$ \\
\hline \multirow[t]{4}{*}{ Gishema } & $\mathrm{GA}_{3}$ & $2385.44^{\mathrm{J}}$ & $2985.88^{\mathrm{BC}}$ & $2950.10^{\mathrm{CD}}$ \\
\hline & $\mathrm{KH}_{2} \mathrm{PO} 4$ & $2427.79^{\mathrm{HIJ}}$ & $2834.87^{\mathrm{CDE}}$ & $2664.39^{\mathrm{EFG}}$ \\
\hline & Water & $2373.08^{\mathrm{J}}$ & $2736.10^{\mathrm{DEF}}$ & $3047.71^{\mathrm{BC}}$ \\
\hline & Control & $2392.76^{\mathrm{IJ}}$ & $2392.76^{\mathrm{IJ}}$ & $2392.76^{\mathrm{IJ}}$ \\
\hline \multirow[t]{4}{*}{ Wello } & $\mathrm{GA}_{3}$ & $3329.98^{\mathrm{A}}$ & $3412.15^{\mathrm{A}}$ & $3406.60^{\mathrm{A}}$ \\
\hline & $\mathrm{KH}_{2} \mathrm{PO} 4$ & $3301.46^{\mathrm{A}}$ & $3390.85^{\mathrm{A}}$ & $3395.24^{\mathrm{A}}$ \\
\hline & Water & $3297.59^{\mathrm{A}}$ & $3418.85^{\mathrm{A}}$ & $3370.48^{\mathrm{A}}$ \\
\hline & Control & $3194.09^{\mathrm{AB}}$ & $3194.09^{\mathrm{AB}}$ & $3194.09^{\mathrm{AB}}$ \\
\hline LSD & & & & 235.26 \\
\hline $\mathrm{CV}$ & & & & 3.89 \\
\hline
\end{tabular}

Where, $\mathrm{PT}=$ Priming type, $\mathrm{GA}_{3}=$ Gibberellic acid, $\mathrm{KH}_{2} \mathrm{PO}_{4}=$ Potassium dihydrophosphate. Means followed by the same letter(s) at each column and row are not significantly different from each other at 0.05 level of probability.

3.1.11. Correlation coefficient(r)

3.1.11.1. Correlation Coefficients between yield and agronomic traits of soybean varieties.

Correlation analysis between seed yield and the other field parameter showed that significant associations were observed between days to 50\% flowering, Harvest index, thousand seed weight, number of pods per plant, number of seed per pods, physiological maturity and stand count at harvest. However, non-significant associations were observed among seed yield, number of primary branches and plant height at maturity (Table 7). There were highly positive correlations between seed yield with number of pods per plant $(\mathrm{r}=0.54)$, number of seed per pods $(\mathrm{r}=0.42)$ and stand count at harvest $(\mathrm{r}=0.45)$ whereas highly negative correlations between seed yield with day to maturity $(\mathrm{r}=$ $-0.71)$, days to $50 \%$ flowering $(\mathrm{r}=-0.67)$, Harvest index $(\mathrm{r}=-0.39)$ and hundred seed weight $(\mathrm{r}=-0.34)($ table 7$)$.

Table 4.Correlation Coefficients(r) between seed yield and agronomic traits of soybean varieties.

\begin{tabular}{llllllllll}
\hline & DF & HI & TSW & NPB & NPPP & NSPP & PHM & PM & SCAH \\
\hline HI & $0.34^{* *}$ & 1 & & & & & & & \\
HSW & $0.41^{* *}$ & $0.20^{\mathrm{NS}}$ & 1 & & & & & & \\
NPB & $0.16^{\mathrm{NS}}$ & $0.11^{\mathrm{NS}}$ & $0.17^{\mathrm{NS}}$ & 1 & & & & & \\
NPPP & $-0.18^{\mathrm{NS}}$ & $0.36^{* *}$ & $0.36^{* *}$ & $0.26^{*}$ & 1 & & & & \\
NSPP & $-0.20^{\mathrm{NS}}$ & $-0.12^{\mathrm{NS}}$ & $-0.07^{\mathrm{NS}}$ & $0.14^{\mathrm{NS}}$ & $0.56^{* *}$ & 1 & & & \\
PHM & $0.24^{*}$ & $0.02^{\mathrm{NS}}$ & $0.49^{* *}$ & $0.62^{* *}$ & $-0.02^{\mathrm{NS}}$ & $0.04^{*}$ & 1 & & \\
PM & $0.53^{* *}$ & $0.30^{* *}$ & $0.49^{* *}$ & $0.24^{\mathrm{NS}}$ & $-0.59^{\mathrm{NS}}$ & $-0.49^{* *}$ & $0.40^{*}$ & 1 & \\
SCAH & $-0.17^{\mathrm{NS}}$ & $-0.41^{* *}$ & $-0.12^{\mathrm{NS}}$ & $0.14^{\mathrm{NS}}$ & $0.62^{* *}$ & $0.38^{* *}$ & $0.17^{\mathrm{NS}}$ & $-0.44^{* *}$ & 1 \\
YIELD & $-0.67^{* *}$ & $-0.39^{* *}$ & $-0.34^{* *}$ & $0.05^{\mathrm{NS}}$ & $0.54^{* *}$ & $0.42^{* *}$ & $-0.12^{\mathrm{NS}}$ & $-0.71^{* *}$ & $0.45^{* *}$ \\
\hline
\end{tabular}

Note, NS, **and * indicates non-significant, highly significant at $1 \%$ and significant at $5 \%$ level of probability respectively. $\mathrm{DF}=$ days to $50 \%$ flowering, $\mathrm{TSW}=$ Thousand Seed Weight $\mathrm{HI}=$ Harvest index $\mathrm{NPB}=$ number of primary branches $\mathrm{NPPP}=$ number of plant per pods $\mathrm{NSPP}=$ number of seed per pods $\mathrm{PM}=$ physiological maturity $\mathrm{PHM}=$ plant height at maturity, $\mathrm{SCAH}=$ stand count at harvest.

\section{Conclusion and Recommendation}

Priming treatment improves or enhanced most of the measured field parameters of the varieties. Under field conditions, there was highly significance $(\mathrm{P} \leq 0.01)$ difference among varieties, priming types, priming durations and their interactions for plant height, number of pods per plants, number of primary branches per plants and yields per hectares. The tallest plant height was recorded for Belessa 95 variety $(87.26 \mathrm{~cm})$ hydro primed for 12 hour, the 
highest number of pods per plant was observed on Belessa 95 variety primed with $\mathrm{KH}_{2} \mathrm{PO}_{4}$ for $12 \mathrm{hr}$ (46.00). Also, highest number of primary branches per plant was observed on Wello and Belessa95variety primed with $\mathrm{KH}_{2} \mathrm{PO}_{4}$ for $12 \mathrm{hr}$ (6.60) and for $6 \mathrm{hr}$ (6.54) respectively. Most of the Priming treatments increases the yields per hectares compared to the controls. The highest yield per hectare was recorded on Wello variety primed with water for $6 \mathrm{hr}$ $(3418.85 \mathrm{Kg})$. Also highly significant $(\mathrm{P} \leq 0.01)$ differences were observed for variety by priming interaction effects for day to $50 \%$ flowering, harvest index, thousand seed weights and significance differences for number of seeds per pods and stand counts at harvest. The lesser days to $50 \%$ flowering ( 82 day) was taken by $W$ ello variety primed with $\mathrm{GA}_{3}$. The highest number of seeds per pods were observed when Wello variety is primed with water (3) and $\mathrm{KH}_{2} \mathrm{PO}_{4}(3)$ and the highest stand count at harvest was recorded for Hydro primed Wello variety (119.67). Correlation analysis between seed yield and the other field parameter showed that significant $(\mathrm{P} \leq 0.05)$ associations were observed between days to $50 \%$ flowering, Harvest index, thousand seed weight, number of pods per plant, number of seed per pods, physiological maturity and stand count at harvest. Generally from field observations soybean varieties primed with water (hydro priming) and $\mathrm{GA}_{3}$ priming Medias showed better results followed by $\mathrm{KH}_{2} \mathrm{PO}_{4}$ on most and each of the measured parameters. Hence, better to recommend for seed growers Hydro priming prior to seed sowing because, simple to use, cost effective and easily available for seed growers to overcome the problems of poor crop emergency and establishments under such adverse environmental conditions comparing to $\mathrm{GA}_{3}$ priming media. However, this study was done only for one season at one location using three varieties, priming media and soaking duration. So that, to give conclusion and recommendations furthermore studies could be made on multiple varieties, priming medias and durations of soaking in research centers, on fields of soybean seed growers and on farmers' fields of different soybean growing areas of Ethiopia.

\section{References}

Aldesuquy, H.S. and Ibrahim, A.H.A., 2000. The role of shikimic acid in regulation of growth, transpiration, pigmentation, photosynthetic activity and productivity of Vigna sinensis plants (Engl.). PHYTONHORN-, 40(2), pp.277-292.

Ali, E. and Kamel, S.G., 2009. Effects of seed priming on growth and yield of chickpea under saline soil. Recent research in science and technology, 1(6).

Amare Belay. 1987. Research Programs of IAR (Institute of Agricultural Research). Addis Ababa, Ethiopia.

Anon.1984. U.S. Soybean production and utilization. Soybean Research. Advance. Institute. DC.P. 69.

Arif, M., Jan, M.T., Marwat, K.B. and Khan, M.A., 2008. Seed priming improves emergence and yield of soybean. Pak. J. Bot, 40(3), pp.1169-1177.

AsARC(Assosa Agricultural Research Center Farming system survey) 2007.Assosa, Ethioipa.

Assefa, M.K., Hunje, R. and Koti, R.V., 2010. Enhancement of seed quality in soybean following priming treatment. Karnataka J Agric Sci, 23, pp.787-789.

Bensen, R.J., Beall, F.D., Mullet, J.E. and Morgan, P.W., 1990. Detection of endogenous gibberellins and their relationship to hypocotyl elongation in soybean seedlings. Plant physiology, 94(1), pp.77-84.

Chavan, N. G., G. B. Bhujbal, and M. R. Manjare. 2014. "Effect of seed priming on field performance and seed yield of soybean [Glycine max (L.) Merill] varieties." The Bioscan 9, no. 1 (2014): 111-114.

Chung, G. and Singh, R.J., 2008. Broadening the genetic base of soybean: a multidisciplinary approach. Critical Reviews in Plant Sciences, 27(5), pp.295-341.

CSA (Central Statistical Agency). 2015. Agricultural Sample Survey 2012/2013: Report on

Farooq, M., Basra, S.M.A., Rehman, H. and Saleem, B.A., 2008. Seed priming enhances the performance of late sown wheat (Triticum aestivum L.) by improving chilling tolerance. Journal of Agronomy and Crop Science, 194(1), pp.55-60.

Gomez, K.A. and Gomez, A.A., 1984. Statistical procedures for agricultural research. John Wiley \& Sons.

Harris, D., Joshi, A., Khan, P.A., Gothkar, P. and Sodhi, P.S., 1999. On-farm seed priming in semi-arid agriculture: development and evaluation in maize, rice and chickpea in India using participatory methods. Experimental Agriculture, 35(1), pp.15-29.

Harris, D., Tripathi, R.S. and Joshi, A., 2002. On-farm seed priming to improve crop establishment and yield in dry direct-seeded rice. Direct seeding: Research Strategies and Opportunities, International Research Institute, Manila, Philippines, pp.231-240.

Harris, D., Rashid, A., Miraj, G., Arif, M. and Shah, H., 2007. 'On-farm'seed priming with zinc sulphate solution-A cost-effective way to increase the maize yields of resource-poor farmers. Field Crops Research, 102(2), pp.119-127.

Solanki, M., Srivastava, S.C. and Jaulkar, A.M., 2013. Growth Pattern of Soybean Cultivation in Madhya Pradesh: District wise Analysis. International Journal of Agriculture, Environment and Biotechnology, 6(4), p.669.

Hymowitz, T., Collins, F.I., Panczner, J. and Walker, W.M., 1972. Relationship between the content of oil, protein, and sugar in soybean seed 1. Agronomy Journal, 64(5), pp.613-616.

IAR (Institute of Agricultural Research). 1982. Soybean production guideline. A.A., Ethiopia. 
Kaur, S., Gupta, A.K. and Kaur, N., 2002. Effect of osmo-and hydropriming of chickpea seeds on seedling growth and carbohydrate metabolism under water deficit stress. Plant growth regulation, 37(1), pp.17-22.

Khairul Mazed, H.E.M. Najmul Haque Md., Israt Jahan Irin, Md. Ashraful Islam Pulok and Abu Habib, Md..2015. Effect of seed priming on growth, yield and seed quality.International Journal of multidisciplinary Research and Development. 2:142-147.

LaRue, T.A. and Patterson, T.G., 1981. How much nitrogen do legumes fix?. In Advances in agronomy (Vol. 34, pp. 15-38). Academic Press.

Liu, K., 1997. Agronomic characteristics, production, and marketing. In Soybeans (pp. 1-24). Springer, Boston, MA.

LIU, K., 2000. Expanding soybean food utilization. Food Technol., 54, pp.46-58.

Masuda, T. and Goldsmith, P.D., 2009. World soybean production: area harvested, yield, and long-term projections. International food and agribusiness management review, 12(1030-2016-82753), pp.1-20.

Mohammadi, G.R., 2009. The effect of seed priming on plant traits of late-spring seeded soybean (Glycine max L.). American-Eurasian Journal of Agricultural and Environmental Science, 5(3), pp.322-326.

Punjabi, B., Mandal, A.K. and Basu, R.N., 1982. Maintenance of vigour, viability and productivity of stored barley seed. Seed research.

Rahman, M.M., Hossain, M.M., Anwar, M.P. and Juraimi, A.S., 2011. Plant density influence on yield and nutritional quality of soybean seed. Asian Journal of Plant Sciences, 10(2), p.125.

Rashid, A., Harris, D., Hollington, P.A. and Rafiq, M., 2004. Improving the yield of mungbean (Vigna radiata) in the North West Frontier Province of Pakistan using on-farm seed priming. Experimental Agriculture, 40(2), pp.233-244.

Ruan, S., Xue, Q. and Tylkowska, K., 2002. The influence of priming on germination of rice (Oryza sativa L.) seeds and seedling emergence and performance in flooded soil. Seed Science and Technology, 30(1), pp.6167.

SAS. 2001. Statistical Analysis System for Windows, release 8.02. SAS Inst., Cary, NC.

Mehri, S., 2015. Effect of seed priming on yield and yield components of soybean. American-Eurasian Journal of Agriculture and Environment Science, 15(3), pp.399-403.

Taylor, A.G. and Harman, G.E., 1990. Concepts and technologies of selected seed treatments. Annual review of phytopathology, 28(1), pp.321-339.

USDA (United States Department of Agriculture). 2016. World agriculture supply and demand estimates, WASDE-549. 